\title{
Štátotvorné úvahy Uhro-Rusínov na konci 1. svetovej vojny - príklon k Československej republike*
}

\author{
ALEXANDER ONUFRÁK**
}

\author{
State-Building Considerations of Uhro-Rusins at the End of World War I - \\ Inclination towards the Czechoslovak Republic
}

\begin{abstract}
In the study, the author tries to explain the socio-political attitudes of the Uhro-Rusins towards the Czechoslovak Republic in the early stages of its origin. The author also attempts to point to several possibilities of co-existence of the Uhro-Rusins in other potential variants, whether as a part of Hungary, independent Ukraine or Russia. One of the variants was also the establishing of an independent state of Uhro-Rusins. Since the American Rusins have played a significant role in this process, the author also deals extensively with the importance and role of the American National Council of Uhro-Rusins and G. I. Žatkovič, who later became the first governor of the Sub-Carpathian Rus. The study is primary based on the historical texts of the main actors of the American National Council of Uhro-Rusins (in particular G. I. Žatkovič, J. G. Gardoš and A. Pop), and secondary on the papers of renowned historians such as P. R. Magocsi, P. Švorc, I. Pop, S. Konečný and others.
\end{abstract}

Keywords: The American National Council of Uhro-Rusins; The Czechoslovak Republic; UhroRus; Uhro-Rusins; G. I. Žatkovič, J. G. Gardoš, Czechoslovak Republic

DOI: $10.14712 / 23363525.2019 .21$

\section{Úvod do problematiky}

Pod pojmom Rusín(i), presnejšie Uhro-Rusín(i) chápeme príslušníkov rusínskeho národa, pričom teritórium, ktoré v minulosti Rusíni vždy obývali, sa nachádzalo pod Karpatským oblúkom v severovýchodnej časti Uhorska a bolo jeho neodlučitel’nou súčastou. Podla oficiálnych štatistických údajov uverejnených v Magyar statiszkai közlemények v roku 1912 i práce ruského etnografa S. Tomaševského pod názvom Ugorskaja Rus z roku 1910, na ktoré sa vo svojej práci Zakliata Krajina: Podkarpatská Rus 1918-1946 odvoláva P. Švorc, bol najvyšší podiel Uhro-Rusínov na celkovom obyvatel'stve v Berežskej župe (48,2 \%), Marmarošskej župe (46,7 \%), Ugočskej župe (40,5 \%) a Užskej župe (38,2 \%), pričom v menšom podieli ešte aj v Šarišskej župe (22,5 \%), Zemplínskej župe (11,6 \%), Spišskej župe (9,4 \%), Báč-bodrožskej župe (1,3\%), Satmárskej župe $(0,4$ \%), Boršodskej župe $(0,1 \%)$ a ojedinele aj inde [Švorc 1996: 6]. Obdobné demografické údaje vo svojej práci udáva aj S. Konečný. ${ }^{1}$

Štúdia je súčastou riešenia grantového projektu KEGA 021 UPJŠ-4/2016 Modernizácia politologického vzdelávania na UPJŠ v Košiciach. Vedúca projektu prof. PhDr. Marcela Gbúrová, CSc.

** Mgr. Alexander Onufrák, PhD., Katedra politológie, Filozofická fakulta, Univerzita Pavla Jozefa Šafárika v Košiciach, Moyzesova 9, 04001 Košice, Slovenská republika. E-mail: alexander.onufrak@upjs.sk

1 Podla S. Konečného najvyšší počet Rusínov v 2. polovici 19. storočia žil v Marmarošskej župe (171 tis., resp. 47,7 \%), Berežskej župe (117 tis., resp. 49,4 \%), Užskej župe (70 tis., resp. 43,3 \%), Ugočskej župe (48 tis., resp. $52 \%$ ), pričom s miernym odstupom nasledovali župy - Zemplínska župa (35 tis., resp. 10,6\%), Šarišská župa (34 tis., resp. 19,4 \%) a Spišská župa (14 tis., resp. 8,3 \%) [Konečný 2015: 119-120]. 
Dnes teritórium obývane Rusínmi zahŕňa celé územie niekdajšej Podkarpatskej Rusi² (dnešná Zakarpatská oblast' Ukrajiny), viaceré prihraničné okresy severovýchodného Slovenska (Prešovský samosprávny kraj), prihraničné oblasti juhovýchodného Polska (Podkarpatské vojvodstvo) ${ }^{3}$, ale tiež prihraničné oblasti severovýchodného Mad’arska (Borsod-Abaúj-Zemplén a Szabolcs-Szatmár-Bereg) a tiež severozápadná oblast' Rumunska (Maramures). Okrem pomenovania Rusín, resp. Uhro-Rusín sa môžeme velmi často stretnút aj s d’alšími pomenovaniami ako Rusnák, Uhro-Rus, Karpato-Rus, Ruthén, Lemko a pod. [Magocsi 1994; Konečný 2015].

S tvrdeniami poniektorých pro-ukrajinsky orientovaných akademikov a autorov, ktorí pojem Rusín považujú za „historicky staršie“ pomenovanie dnešného Ukrajinca, teda za jeho synonymum, sa dá súhlasit len vo velmi oklieštenej miere, a to len v tom prípade, ak toto pomenovanie etymologicky upresníme a teda, že hovoríme o tzv. Haličských Rusínoch. Tí predstavovali obyvatel'stvo obývajúce teritórium niekdajšej Haliče pod správou Rakúska, pričom dnes ide o oblasti západnej časti Ukrajiny, presnejšie o oblast' Ivano-Frankivsku, Lvivsku a Ternopil’sku, ale aj o niektoré prihraničné regióny na východe Pol’ska.

Vzhladom na odlišný historicko-politický vývoj v rámci Rakúska a Uhorska, a teda i medzi oboma vyššie zmienenými entitami, je zretelný rozdiel nie len pokial ide o spoločensko-politický kontext, ale aj pokial ide o kontext ekonomický, jazykový, kultúrny, národný či náboženský. ${ }^{4} \mathrm{Z}$ tohto dôvodu nie je možné tieto dva národy zlučovat do jedného, ako to poniektorí v minulosti často robili a ešte aj dnes stále robia. Na druhej strane, nepopierame, že v minulosti medzi haličskými a uhorskými Rusínmi a aj Rusínmi z Bukoviny jestvovali (aj pomerné čulé) väzby.

Pokial' ide o ekonomicko-politické a kultúrno-spoločenské postavenie Uhro-Rusínov v rámci Uhorska, územia obývané Uhro-Rusínmi vždy patrili k tým najchudobnejším a najzaostalejším. Ešte aj na začiatku 20. storočia značná čast’ obyvatel'stva pritom pracovala v polnohospodárstve alebo pri tažbe a spracovaní dreva. Kým na severovýchode Slovenska predstavoval podiel ekonomicky aktívneho obyvatel'stva pracujúceho v oblasti polnohospodárstva približne $70 \%$, tak v prípade územia Uhorskej Rusi bol tento podiel

2 Nakolko zemepisné označenie Podkarpatská Rus sa začalo používat’ až v Československej republike od roku 1920 a to prijatím Zákona č. 121/1920 Sb. zo dňa 29. februára 1920, ktorým sa uviedla Ústavná listina Československej republiky, v celej štúdií na označenie územia obývané uhorskými Rusínmi pokial' bolo súčastou Uhorska budeme používat' geografické označenie Uhorská Rus.

3 Značná čast’ pôvodného lemkovského obyvatel'stva bola v 50. rokoch 20. storočia z tohto regiónu násilne presídlená do iných regiónov v rámci Pol'ska počas tzv. Akcie Visla. Predovšetkým do okolia mesta Wroclaw, či prímorských miest Baltského mora - Gdańsk, Gdynia a Szczecin.

4 Ako príklad toho, že medzi haličskými Rusínmi a uhorskými Rusínmi bol (a stále je) rozdiel, je možné uviest’ aj udalosti, ktoré sa odohrali počas 19. a 20. storočia. Spomedzi nich je možné spomenút napríklad konanie Slovanského zjazdu v Prahe medzi 2.-12. júnom 1848 [bližšie o Slovanskom zjazde: Černý 1888]. Kým haličskí Rusíni svojich zástupcov na zjazde mali, pričom boli zaradení do spoločného okruhu s Poliakmi, tak z uhorských Rusínov nebol na Slovanskom zjazde prítomný nikto. Vzhladom na túto skutočnost’ bol J. M. Hurban ako zástupca Slovákov požiadaný zástupcom haličských Rusínov I. Borisikevičom, aby zostavil a predniesol požiadavky nielen za Slovákov, ale aj za uhorských Rusínov. Toto vyhlásenie je známe aj ako Žiadosti Slovákov a Rusínov (uhorských), pričom pozostával zo siedmych bodov. Zaujímavostou tohto textu je, že aj ked’ sa v celom Hurbanovom texte spomínajú uhorskí Rusíni, v názve tohto dokumentu vypublikovaného v roku 1962 zostavovatelia uviedli, že išlo o Žiadosti Slovákov a Ukrajincov uhorských. Zostavovatelia zároveň konštatovali, že „išlo o prvý doklad slovensko-ukrajinskej politickej spolupráce v Uhorsku“. Toto, vzhladom na vyššie uvedené skutočnosti ohladne zástupcov haličských Rusínov, považujeme nielenže za nereálne, ale priamo za zámerný a vedomý klam, ktorý len kopíroval postoje vtedajšej politickej reprezentácie k Rusínom [Bokeš 1962: 25-27]. 
ešte vyšší, pričom sa približoval až k 90 \% [Konečný 2015]. Za najčastejšie príčiny, ale aj následky tohto stavu možno považovat:

- absolútnu absenciu politických elít medzi Uhro-Rusínmi; 5

- takmer neexistujúcu rusínsku inteligenciu, pričom aj tí, ktorí ju tvorili, sa koncentrovali najmä v rámci gréckokatolíckeho duchovenstva;

- odnárodňovanie a silné pomad’arčovanie;

- orientácia na viaceré smery a prúdy (pro-mad’arský, pro-ukrajinský, pro-ruský, pro-rusínsky) mali značný vplyv na vnútornú nejednotnost’ a fragmentáciu Uhro-Rusínov, čo malo za následok i časté nezhody a konflikty v rámci samotného rusínskeho hnutia;

- rozpory v rámci duchovenstva, a to nie len medzi gréckokatolíkmi a pravoslávnymi, ale aj v rámci jednej cirkvi v závislosti od príslušností k etniku. Tento rozpor bol najmä medzi pro-rusínsky a pro-madarsky orientovanými duchovnými gréckokatolíckej cirkvi, pričom bokom nezostali ani pro-slovenskí či pro-ukrajinskí duchovní. Čast’ gréckokatolíkov dokonca konvertovala na pravoslávie, a to tak doma, ako aj v USA; ${ }^{6}$

- neexistencia spisovného rusínskeho jazyka, ale aj nekonečné debaty a spory o zachovaní cyriliky, resp. prijatí latinky;

- neexistencia vlastných vzdelávacích, kultúrnych a politických organizácií;

- na prelome 19. storočia a 20. storočia silná vystahovalecká vlna najmä do USA, no v menšej miere i do Kanady, štátov Latinskej Ameriky či do Belgicka.

V súvislosti s emigráciou uhorských Rusínov je potrebné povedat, že do roku 1914 sa len z územia Uhorskej Rusi do USA vystahovalo približne 155 tisíc osôb, čo predstavovalo takmer 1/3 jej vtedajšieho obyvatel'stva [Švorc 1996]. Podla P. R. Magocsiho celkový počet Uhro-Rusínov, ktorí do USA medzi rokmi 1880 až 1914 prišli, nebol nižší než 225 tisíc osôb, pričom vychádzal z migračných štatistík USA. Pritom podla oficiálnych uhorských štatistík to bolo za to isté obdobie len približne 60 tisíc osôb [Magocsi 2005]. Americká Národná rada Uhro-Rusínov v rokoch 1918-1919 odhadovala počet Uhro-Rusínov žijúcich v USA až na približne pol milióna [ANRU-R 1919]. I. Mrva a V. Segeš vo svojej knihe Dejiny Uhorska a Slováci uviedli, že „len v rokoch 1899 až 1907 počet osôb, ktoré sa z Uhorska

5 Táto absencia pretrvávala od 70. rokov 19. storočia, čo do značnej miery súviselo s rakúsko-uhorským vyrovnaním. Do tohto obdobia je možné spomenút spoločensko-politické aktivity takých osobnosti Uhro-Rusínov, akými boli A. I. Dobriansky, A. Duchnovič, A. Pavlovič, ale aj mnohí d’alší (A. Kralicky, J. Stavrovský-Popradov, I. Danilovič-Korytňanský atd.).

6 V tejto súvislosti je možné spomenút napríklad konflikt z roku 1891 medzi rusínskymi gréckokatolíckymi duchovnými a katolíckou hierarchiou v USA kvôli celibátu. Čast’ gréckokatolíckych veriacich, ale aj duchovných konvertovala na pravoslávie. V roku 1894 vznikol d’alší konflikt medzi gréckokatolíkmi z Haliče a rusínskymi gréckokatolíkmi z Uhorska, ktorí odmietali ukrajinskú orientáciu. Rozkol medzi oboma skupinami sa najviac prejavil v roku 1907, ked' Vatikán za gréckokatolíckeho biskupa pre USA vymenoval haličského duchovného ukrajinskej orientácie S. S. Ortynského. Rozpory medzi predstavenými gréckokatolíckej cirkvi a organizáciou združujúcou Rusínov pod názvom Sojedinenije Greko-Katholičeskich Russkich Bratstv vyvolalo vznik novej rusínskej organizácie, a to Sobranije Greko-Katholičeskich Cerkovnich Bratstv. Kedže uhorskí Rusíni odmietli uznat' biskupa S. S. Ortynského za svojho biskupa, v roku 1918 musel Vatikán rozdelit’ gréckokatolícku cirkev v USA na dve, na ukrajinskú a rusínsku. Po smrti biskupa S. S. Ortynského v roku 1916 považovalo Sojedinenije Greko-Katholičeskych Russkich Bratstv za najvhodnejšieho kandidáta na biskupský stolec o. A. S. Dzubaya. Ked' sa biskupom nestal, nespokojný o. A. S. Dzubay konvertoval na pravoslávie. Po ôsmich rokoch sa však opät vrátil do gréckokatolíckej cirkvi [Pop 2011; Magocsi 2005]. V Uhorsku boli hlavnými dôvodmi prechodu rusínskych grékokatolíkov na pravoslávie najmä sociálno-ekonomické aspekty (platenie tzv. rokoviny a kobliny), ale aj madarizácia. Uhorská vláda v prechode časti rusínskeho obyvatel’stva z gréckokatolíckej viery na pravoslávie videla aj politický aspekt, teda priblíženie sa k ruskému štátu. To bol aj prípad tzv. Marmarošského procesu v dňoch 29. decembra 1913 až 3. marca 1914 [Švorc 1996; Pop 2005]. 
vystahovali do Ameriky, dosiahol úroveň 740 tisíc, pričom do začiatku 1. svetovej vojny sa v Amerike natrvalo usadilo 600 tisíc našich krajanov"7 [Mrva - Segeš 2012: 331]. Na týchto príkladoch je možné jasne vidiet', že medzi uverejnenými štatistikami existujú značné rozdiely, a to v závislosti od toho, kto a za akých podmienok tieto údaje zhromaždil a uverejnil.

Najvyšší počet Uhro-Rusínov sa pritom koncentroval v štátoch Pennsylvánia, New York, New Jersey, Ohio a Connecticut a v menšej miere aj v štátoch Indiana, Illinois, Michigan, Minnesota, ale aj inde. Prevažná väčšina Uhro-Rusínov sa pritom sústredovala v priemyselných oblastiach, v ktorých dominovalo baníctvo a hutníctvo. I ked’ na jednej strane je možné vystahovalectvo Uhro-Rusínov považovat’ za istú tragédiu národa, na druhej strane, práve vd’aka emigrácii sa tento národ sociálno-ekonomicky, ako aj občiansko-politicky povzniesol na úplne novú úroveň.

Hlavným cielom tejto práce je poukázat na štátotvorné úvahy Uhro-Rusínov na konci 1. svetovej vojny s dôrazom na príklon k novovzniknutej Československej republike.

\section{Uhro-Rusíni na križovatke dejín}

Najvýznamnejšie úvahy o štátoprávnom usporiadaní Uhro-Rusínov pochádzajú z 2. polovice 19. storočia, pričom za najvýznamnejšiu politickú osobnost' uhorských Rusínov v tomto období sa ešte aj dnes považuje národný buditel' Uhro-Rusínov a vtedajší poslanec Uhorského snemu A. I. Dobriansky. Od 70. rokov 19. storočia až do ukončenia 1. svetovej vojny v roku 1918 uhorskí Rusíni v rámci Uhorska v podstate nemali žiadnu výraznejšiu politickú reprezentáciu, ktorá by sa ich zastávala a navonok reprezentovala.

Na konci 1. svetovej vojny, v súvislosti so štátoprávnym usporiadaním územia Uhorskej Rusi, prichádzalo do úvahy hned' niekolko variantov:

1. Uhorská Rus ako autonómna súčast' Mad’arska;

2. Uhorská Rus ako samostatný štát;

3. Uhorská Rus ako súčast' Ruska;

4. Uhorská Rus ako súčast’ zjednotenej Ukrajiny;

5. Uhorská Rus ako súčast’ novovznikajúcej Československej republiky.

Každá koncepcia sa opierala o isté predpoklady (historické, kultúrne, jazykové, náboženské, ekonomické atd'.), pričom ich protagonistami boli najmä jednotlivci i skupiny intelektuálov prikláňajúcich sa ku konkrétnemu variantu. Štátotvorné koncepcie pritom nevychádzali „zdola“, teda od bežných ludí, ale výlučne od intelektuálnych a politických elít. Tie chceli existujúce spoločensko-politické pomery (a často aj svoje vlastné postavenie) bud' udržat' - to bol prípad pro-madarskej orientácie, alebo ich naopak zásadným spôsobom zmenit', a to podla toho, ako sa menili vtedajšie okolnosti a udalosti.

Pod „našimi krajanmi“ mali autori na mysli (spoločne) Slovákov a Rusínov, pričom ako vyššie v texte uvádzajú, „ako prví odchádzali obyvatelia východného Slovenska, najmä neúrodou postihnutého Zemplína, Šariša a Spiša, no od konca 80. rokov 19. storočia sa húfne stahovali do Ameriky aj obyvatelia z ostatných kútov Slovenska“. 


\subsection{Uhorská Rus ako autonómna súčast' Mad’arska}

Na konci 1. svetovej vojny na územiach dovtedy patriacich pod správu Rakúsko-Uhorskej monarchie zavládol dovtedy nepredstavitelný chaos. Z danej situácie, ktorá bola značne neprehladná a o to viacej nepochopitelná, chcel každý národ pre seba vytažit čo najviac. Kým dovtedy porobené národy sa z nastolenia nových pomerov nesmierne tešili, kedže v nich videli nové výzvy, tak zástancovia starých pomerov sa snažili zachránit, čo sa len dalo. V tomto duchu sa niesla aj propagandistická kampaň madarskej vlády pod vedením M. Karolyiho. Zachovaniu územnej celistvosti Uhorska už nepomohol ani predložený návrh tzv. Podunajských spojených štátov, ktorý detailne rozpracoval madarský minister pre národnosti O. Jászi. Niekdajšie Uhorsko sa tak malo stat federatívnym štátom - presnejšie akýmsi „východným Švajčiarskom“ [Danilák in. Švorc - Danilák - Heppner (ed.) 2002]. Jediní, kto na túto mad’arskú ponuku na autonómiu pristúpili, boli poniektorí pro-mad’arskí Uhro-Rusíni.

5. novembra 1918 sa v Užhorode (za súhlasu vtedajšieho mukačevského sídelného biskupa A. Pappa) stretli gréckokatolícki duchovní pro-mad’arskej orientácie, ktorí rozdiskutovali vzniknutú situáciu, pričom sa vyslovili za zotrvanie uhorských Rusínov v spoločnom zväzku s Mad’armi. Na čelo tohto výboru sa postavil o. A. Vološin. Už o štyri dni neskôr t. j. 9. novembra 1918 došlo v Užhorode k zvolaniu ludového zhromaždenia, na ktorom bola vytvorená Uhro-Ruská Národná rada. Za jej predsedu bol zvolený o. S. Szabó, pričom o. A. Vološin sa stal jej jednatelom. Zároveň bolo prijaté memorandum, v ktorom sa prítomní vyslovili za celistvost' mad’arského štátu, no od madarskej vlády pre Uhro-Rusínov delegáti požadovali rovnaké práva, aké mali mat’ aj ostatné národy tohto štátu; autonómnu správu pre gréckokatolícku cirkev; zriadenie katedry ruského - teda rusínskeho jazyka na univerzite v Budapešti; ale aj nastolenie hospodárskych reforiem [Švorc 1996; Pop 2005].

Vzhladom na rýchlo sa meniace udalosti už 10. decembra 1918 bolo v Budapešti zvolané národné zhromaždenie Rusínov, ktorého sa mala zúčastnit len lojálna pro-mad’arsky orientovaná rusínska inteligencia, s cielom potvrdit zotrvanie Uhro-Rusínov v rámci Mad’arska. Kedže sa tohto zhromaždenia zúčastnili aj pro-ukrajinsky orientovaní Rusíni z Chustu a Jasini - konkrétne J. Braščajko, P. Dolinaj a Š. Kločurak, ${ }^{8}$ ktorí proklamovali pripojenie Karpatskej Rusi k Ukrajine, k očakávanému záveru zhromaždenia, a to deklarovat’ prináležitost' Uhro-Rusínov k Mad’arsku, napokon nedošlo. Jedným z vyvrcholení týchto udalostí bolo aj vyhlásenie pro-ukrajinsky orientovaných Rusínov, že budapeštianske zhromaždenie nemá žiadne kompetencie rozhodovat’ o osude podkarpatských Rusínov, ako aj to, že „d’alšie národné zhromaždenie sa má konat na vlastnej pôde, a nie na cudzej v Budapešti“ [Švorc 1996: 18-19; Pop 2005: 281].

Na základe takéhoto politického vývoja mad’arská vláda ešte dňa 21. decembra 1918 zriadila zákonom č. X z toho istého dňa v rámci Madarskej republiky rusínsku autonómnu oblast' pod názvom Ruská Krajna. ${ }^{9}$ Ruská Krajna zahŕňala župy Marmaroš, Bereg, Uh a Ugoča, pričom hranice územia boli určené len dočasne, kým nebudú vyznačené medzinárodnou mierovou konferenciou. Aj ked’ rusínska reprezentácia požadovala do

P. Švorc vo svojej knihe udáva ešte aj J. Čučka [Švorc 1996].

9 M. Danilák poukazuje na fakt, že mnohí autori na označenie tohto územia používajú v ukrajinčine i slovenčine termín Ruská Krajina, čo je podla neho nesprávne [Danilák in. Švorc - Danilák - Heppner (ed.) 2002: 61]. 
autonómnej oblasti Ruskej Krajny zahrnút aj Zemplínsku, Šarišskú, Spišskú a Abovskú župu, kedže aj tu žili uhorskí Rusíni, mad’arská vláda s týmito požiadavkami v podstate nepočítala. Po prvé, preto, že išlo o župy, kde Rusíni predstavovali menšinu a po druhé, že mad’arská vláda sa nechcela dostat’ do konfliktu s d’alšími nemad’arskými národmi bývalého Uhorska.

Po tom, čo 8. januára 1919 boli mestá Užhorod, Mukačevo, Berehovo, Marmarošská Sihot', Sevluš (dnes Vinohradovo) a dokonca i Sval'ava a Solotvyna, ako aj okresy Berehovský, Sevlušský a Ťačevský vyhlásené za integrálnu súčast’ Mad’arska, sa odpor voči budapeštianskej vlády vzniesol i zo strany promadarsky orientovaných Uhro-Rusínov [Danilák in. Švorc - Danilák - Heppner (ed.) 2002].

4. marca 1919 sa na území Ruskej Krajny, ktoré ešte nebolo obsadené československým vojskom konali, volby do Rusínskeho národného zhromaždenia, pričom účast' voličov v nich bola príliš nízka. V nasledujúci deň - 5. marca 1919 sa v Mukačeve konalo 1. zasadnutie novozvoleného národného zhromaždenia, ktoré pozostávalo z 36 zástupcov. Na návrh K. Hrabara namiesto schválenia vládneho programu prítomní poslanci mad’arskej vláde ultimátne oznámili, že zhromaždenie sa opätovne zíde až potom, ako madarská vláda vytýči hranice Ruskej Krajny, ktoré uspokoja Rusínov. Podla M. Daniláka, ktorý sa vo svojej práci odvoláva na P. Sterča, to bol v podstate „faktický koniec autonómie v réžii Karolyiho vlády“ [Danilák in. Švorc-Danilák-Heppner (ed.) 2002: 62].

Pokial ide o pro-mad’arsky orientovanú skupinu Rusínov v USA, najčastejšie sa spomínajú o. N. Chopey, M. Yuhasz, o. M. Balogh, a o. V. Tegza [Danko 1968]. (Zkratka „o.“je otec - ako duchovny otec, respektive farár.)

\subsection{Uhorská Rus ako samostatný štát}

S týmto variantom sa najčastejšie stretávame najmä medzi častou rusínskej reprezentácie v USA. Medzi najvýznamnejších podporovatelov tohto variantu patrili o. J. P. Hanulya, J. G. Gardoš, o. V. Gorzó, o. A. Pop, o. T. Žatkovič a G. I. Žatkovič [Danko 1968]. Potom, ako táto skupina zistila, že vznik samostatného štátu Uhro-Rusínov nie je možný, všetci si osvojili myšlienku spolužitia v spoločnom štáte s Čechmi a Slovákmi na federatívnom princípe.

Existenciu troch „rusínskych republík“ - Huculska republika, ${ }^{10}$ Rusínska l’udová republika Lemkov ${ }^{11}$ a Komančanská republika ${ }^{12}$ - možno vnímat len ako „prechodné útvary“, ktoré len tažko možno považovat’ za štátno-politické subjekty v pravom zmysle slova.

10 V prípade Huculskej republiky išlo o štátny útvar, ktorého trvanie bolo približne len pol roka, a to od 8. januára 1919 do 11. júna 1919. Hlavné mesto bolo zriadené v meste Jasiňa. Huculská republika nebola uznaná žiadnym štátom [bližšie o Huculskej republike napríklad Pipaš 2009].

11 Rusínska ludová republika Lemkov vznikla po rozpade Rakúsko-Uhorska, ked' sa vo Florynke (dnes Polsko) dňa 5. decembra 1918 zišlo 500 delegátov zo 130 lemkovských obcí, aby vytvorili výkonnú radu schopnú zjednotit Rusínov žijúcich na oboch stranách Karpát do štátu, ktorý by sa mohol pripojit’ k Rusku. Vzhladom na vypuknutie občianskej vojny v Rusku sa tieto úvahy neskôr ukázali ako nereálne. Aj v tomto prípade došlo k rozporom v rámci rusínskeho hnutia. Kým čast̉ delegátov sa prikláňala k pripojeniu k Rusku, iná inklinovala k Ukrajine a dalšia k novovzniknutej Československej republike [bližšie pozri: Magocsi 1993].

12 Komančanská republika sa niekedy označuje aj ako Lemkovská republika. Trvanie tejto republiky bolo pomerne krátke, a to od 5. novembra 1918 do 27. januára 1919. Na rozdiel od Rusínskej ludovej republiky Lemkov vo Florynke, ktorej cielom bolo hájit záujmy Rusínov - Lemkov, Komančanská republika so sídlom v Komańczi (dnes Pol’sko) sa prikláňala k ukrajinskej orientácii, presnejšie k novovzniknutej Západoukrajinskej ludovej 


\subsection{Uhorská Rus ako súčast' Ruska}

V súvislosti s variantom, ktorý uvažoval o pripojení Uhorskej Rusi k Rusku, je potrebné povedat', že v zásade nešlo o nové úvahy, kedže totožné úvahy sa už objavili omnoho skôr - konkrétne v 2. polovici 19. storočia, a to najmä v prácach A. I. Dobrianskeho. V tomto období to v regióne strednej Európy nebolo nič výnimočné, nakol'ko obdobné úvahy o pripojení slovanských národov $\mathrm{k}$ Rusku je možné vidiet’ u celého radu vtedajších národných buditelov, vrátane mnohých Slovákov, Čechov, Srbov či Chorvátov [bližšie pozri napr. Gbúrová 2002; Gbúrová in. Krno 2017].

V období tesne po skončení 1 . svetovej vojny sa s orientáciou karpatských Rusínov na Rusko opätovne stretávame najmä pri Rusínskej ludovej republike Lemkov, ale aj medzi reprezentantmi Ruskej národnej rady so sídlom v Prešove, či u niektorých amerických Uhro-Rusínov združených v organizácii Amerikanska Ruska Národná Obrana. ${ }^{13}$ Hlavnými protagonistami tejto organizácie boli N. Pačuta, P. Hatalak, P. Dzwončik a o. E. Kubek. Táto organizácia bola známa aj vd’aka pomerne čulej spolupráci s pro-ruskými imigrantmi z Haliče a Bukoviny a podporovaná Rusmi žijúcimi v USA. ${ }^{14}$

Vzhladom na politický vývoj v Rusku začali predstavitelia Národnej Obrany po roku 1917 postupne upúštat’ od orientácie na Rusko a v čoraz väčšej miere prijímali ideu pripojenia Uhorskej Rusi - avšak spoločne s Haličou a Bukovinou - k Československu. V apríli 1918 dokonca v tejto veci predložili memorandum vtedajšiemu ministrovi vnútra USA R. Lansingovi. 30. mája 1918 sa N. Pačutovi (aj vd’aka pomoci amerických Slovákov) podarilo stretnút' s T. G. Masarykom v snahe informovat' ho o tomto projekte. Aj ked' postoj T. G. Masaryka k Pačutovmu projektu pripojit’ k Československej republike nie len Uhorskú Rus, ale aj Halič a Bukovinu bol vzhladom na jeho nerealizovatel'nost'15 hned' od začiatku zamietavý, v každom prípade je potrebné vyzdvihnút tú skutočnost', že išlo de facto o prvý pokus politického priblíženia Uhro-Rusínov k Čechom a Slovákom.

republike (dalej ZUNR), ktorá existovala od 1. novembra 1918 do 18. júla 1919, ked’ bola obsadená polskými jednotkami a o čosi neskôr pripadla Polsku.

13 Prvý kongres tejto skupiny sa konal v New Yorku 13. júla 1917. Výsledkom kongresu bolo schválenie začlenenia Karpatskej Rusi ako autonómnej jednotky v rámci Ruska vo forme momeranda, ktoré P. Hatalak a P. Dzwončik prezentovali ruskému velvyslancovi vo Washingtone D. C. B. Bakhmeteffovi. Zo strany ruských delegátov bolo toto memorandum upravené, a to $\mathrm{v}$ tom zmysle, že bol z neho vynechaný dôraz na autonómiu $\mathrm{v}$ rámci Ruska, čo bolo ospravedlňované tým, že by tento pojem mohol byṫ zo strany ruského partnera a jeho dobrej vôle nesprávne pochopený. Memorandum bolo následne preložené do viacerých jazykov a zaslané Američanom, Britom i dalším spojeneckým vládam [Danko 1968].

14 V súvislosti s aktivitami Amerikanskej Ruskej Národnej Obrany (skrátene Národnej Obrany) delegát J. G. Gardoš na Zasadnutí Národného kongresu Amerikanskich Rusínov pod ochranou a vedením Americkej národnej rady Uhro-Rusinov konanej v Homestead, Pa., $v$ dňoch 15.-16. septembra 1919 povedal: „Národnú Obranu zničili ludia bolšsevických princípov, pričom hlavným princípom ruských bolševikov je neverstvo národa. Oni ničia všetko, čo národ drží pri Bohu, pri cirkvi, pri spoločenskom poriadku. Oni sa pokúšali dotknút najväčšieho pokladu uhro-ruského národa - jeho svätej viery. Pokúsili sa medzi americkými Rusínmi zasiat’ taký zmätok, aký sa im podaril v Rusku" [ANRU-R 1919: 88-89].

15 Pri stretnutí s N. Pačutom si T. G. Masaryk velmi dobre uvedomoval tri zásadné skutočnosti: 1 . K novovzniknutej Československej republike nebude možné pripojit Halič a Bukovinu; 2. T. G. Masarykovi boli známe predošlé aktivity Národnej Obrany a jej pro-ruská orientácia; 3. Medzi americkými Rusínmi mali N. Pačuta, ako aj Národná Obrana príliš nízku podporu [Danko1968]. 


\subsection{Uhorská Rus ako súčast’zjednotenej Ukrajiny}

Pokial' ide o pripojenie území obývaných uhorskými Rusínmi k novovzniknutej Ukrajine, realizovatelnost' tohto variantu sa javila hned' od začiatku za omnoho pravdepodobnejšiu, ako to bolo $\mathrm{v}$ predošlých troch prípadoch. Miera realizovatelnosti tohto variantu obzvlášt vzrástla potom, ako Nemecko a Rakúsko-Uhorsko 9. februára 1918 uznali Ukrajinu za samostatný štát a podpísali s ňou separátne mierové zmluvy.

Za obzvlášt významný dátum možné považovat' 8. november 1918. V tento deň nielenže došlo k ludovému zhromaždeniu v Jasini (juhovýchodná čast’ Marmarošskej župy), ktoré podporilo požiadavku sformulovanú Š. Kločurakom, aby sa Uhorská Rus pripojila k Ukrajine, pričom bola vyhlásená aj tzv. Huculská republika, ale nezávisle na tomto zhromaždení došlo aj k stretnutiu v Starej L'ubovni, kde bola z iniciatívy E. Nevického, ktorý najhlasnejšie proklamoval pro-ukrajinskú orientáciu, založená Ruská národná rada, ${ }^{16}$ ktorá následné prijala uznesenie o zjednotení uhorských Rusínov s Ukrajinou. 17. novembra 1918 došlo v Chuste ku vzniku Ruskej (ukrajinskej) národnej rady, ktorá taktiež vyslovila požiadavku pripojenia územia Uhorskej Rusi k Ukrajine. Samotnú požiadavku pritom predniesol jej predseda J. Braščajko, a to najprv 10. decembra 1918 v Budapešti, pričom opätovne bola nastolená 21. januára 1919 na zhromaždení v Chuste [Pop 2005].

8. decembra 1918 vznikla v Svalave Karpatská Ruská Národná Rada, na ktorej čele stál M. Komarnický, pričom ostro odsúdila pro-mad’arský orientovanú Uhro-Ruskú Národnú radu so sídlom v Užhorode a tiež sa vyjadrila za pripojenie k Ukrajine. Posledná v poradí pro-ukrajinsky orientovaná národná rada vznikla v Marmarošskej Sihoti dňa 18. decembra 1918 a na jej čelo sa postavil M. Braščajko. Výstižné sú v tejto neprehladnej situácii slová historika I. Popa, ktorý vznik hned’ viacerých národných rád Uhro-Rusínov opísal nasledovne: „Na území od Popradu po Jasiňu na juhovýchode a po Lemkovinu na severovýchode vznikol celý rad tzv. národných rád rôznorodej orientácie“ [Pop 2011: 66].

Po obsadení Ukrajiny bolšsevickou armádou v roku 1919 a potom, ako mierová konferencia v Paríži neuznala samostatnost' Ukrajiny, sa tieto úvahy rozplynuli a za najreálnejší vývoj viacerí (aj pro-ukrajinskí) protagonisti považovali pripojenie Uhorskej Rusi k Československej republike.

\subsection{Uhorská Rus ako súčast' novovznikajúcej Československej republiky}

O spojení Uhro-Rusínov so Slovákmi a Čechmi v rámci spoločného štátu sa začalo medzi Uhro-Rusínmi v USA hovorit’ až niekedy na prelome prvého a druhého polroka 1918. Samotná idea spolupráce medzi uhorskými Rusínmi a Slovákmi vychádzala v podstate zo spoločných skúseností, problémov i spolunažívania doma v Uhorsku i v emigrácii v USA. Táto spolupráca sa prejavovala v každodennom živote i vo vzájomnom povzbudzovaní jedných druhými a naopak. ${ }^{17}$ Česká politická reprezentácia až do tohto obdobia o spo-

16 Dňa 19. novembra 1918 sa sídlo Ruskej národnej rady zo Starej L’ubovne prenieslo do Prešova. Jej vedenie postupne ovládla skupina okolo A. Beskyda, ktorá proklamovala orientáciu na Československo, pričom postupne vytlačovali z diania pro-ukrajinsky orientovaných aktivistov na čele s E. Nevickým. Už o dva dni neskôr sa prešovská Ruská národná rada spojila s Ruskou radou Lemkov na čele s A. Gagatkom a D. Vyslockým a vytvorili Karpato-rusku národnu radu [Pop 2011].

17 O spolkovej spolupráci medzi Uhro-Rusínmi a Slovákmi píše napríklad P. R. Magocsi [Magocsi 2005]. 
jení s Uhro-Rusínmi a ani o území, ktoré Uhro-Rusíni obývali, v podstate neuvažovala. Toto územie bolo podla nej chápané ako sféra, ktorá patrí Rusku ${ }^{18}$ [Švorc 1996].

30. mája 1918 sa v Pittsburghu (Pennsylvánia) N. Pačuta (tentokrát už ako podporovatel' pripojenia uhorských Rusínov k Československej republike) stretol s T. G. Masarykom, aby spoločne prekonzultovali vzájomnú existenciu v spoločnom štáte. T. G. Masaryk, vedomý si predošlej pro-ruskej orientácie N. Pačutu i jeho tendencie okrem Uhorskej Rusi pripojit k Československej republike ešte aj Halič a Bukovinu, vzal tento návrh, presnejšie memorandum, na vedomie pomerne vlažne. V každom prípade možno hovorit’ o prvom kroku politického priblíženia uhorských Rusínov k Čechom a Slovákom.

Vzhladom na dovtedajšiu vnútornú rozdrobenost’ a nejednotnost’ v rámci rusínskej emigrácie v USA bolo prvoradým cielom jej hlavných protagonistov zjednotit postoje vo vnútri hnutia s cielom vystupovat navonok ako jedna integrálna societa. To sa odohralo v júni 1918 v meste Cleveland (Ohio), kde sa konal zjazd rusínskych organizácii, ktorý sa následne presunul do mesta Braddock (Pennsylvánia). Na zjazde došlo nielen k zosadeniu N. Pačutu z čela rusínskeho hnutia, ale predovšetkým k vytvoreniu komisie, ktorá mala pripravit’ spoločné stretnutie, na ktorom by sa stretli zástupcovia najvýznamnejších rusínskych organizácii, a to Sojedinenije Greko-Kaftoličeskich Russkich Bratstv ${ }^{19}$ (dalej Sojedinenije) a Sobranije Greko-Katholičeskich Cerkovnych Bratstv ${ }^{20}$ (dalej Sobranije). Stalo sa tak 23. júla 1918 v Homesteade (Pennsylvánia), ked’ sa zástupcovia oboch organizácii stretli, aby prediskutovali, čo by bolo pre budúcnost' Uhro-Rusínov najlepším riešením. Argumentovalo sa za i proti spojeniu s Madarmi, Čechoslovákmi, Ukrajincami i Rusmi. Za najväčší prínos je však možné považovat to, že sa prítomní spoločne zhodli na vzájomnej spolupráci v prospech rusínskeho národa a na záver stretnutia zostavili politický program Americkej Národnej Rady Uhro-Rusínov ${ }^{21}$ (d’alej ANRU-R). Direktórium ANRU-R pritom pozostávalo z 9 zástupcov Sojedinenija, 9 gréckokatolíckych duchovných, 2 zástupcov Sobranija a 3 učitelov. Dokopy teda išlo o 23 reprezentantov. Za predsedu ANRU-R bol zvolený o. N. Chopey.

18 Na druhej strane, T. G. Masaryk sa už v lete 1917 počas svojho pobytu v Kyjeve „dotkol“ budúcnosti Uhorskej Rusi, ked’ mu predstavitelia Centrálnej rady v Kyjeve oznámili, že majú záujem o Halič a Bukovinu a že nemajú nič proti pripojeniu Uhorskej Rusi k budúcej Československej republike [Pop 2005].

19 Táto organizácia vznikla v roku 1892 v meste Wilkes-Barre (Pennsylvánia), aby združovala gréckokatolíkov, ktorí rozprávali po rusínsky. Počet členov pri zrode organizácie bol 743 v rámci 14 miestnych organizácií. Prvým predsedom organizácie bol J. Žinčak Smith. Organizácia vydávala noviny Amerikanskij Ruskij Viestnik, na čele ktorého dlhé roky stál P. Žatkovič - otec G. I. Žatkoviča. V roku 1905 sa sídlo organizácie prestahovalo do Homesteadu (Pennsylvánia). V 20. rokoch 20. storočia už išlo o najväčšiu a najsilnejšiu rusínsku organizáciu, ktorá v tom čase združovala 95 tisíc členov. Najvyšší počet členov organizácie bol v roku 1929, ked’ ich počet dosiahol 133 tisíc, a to v rámci 1719 miestnych organizácií [Magocsi 2005].

20 Táto rusínska organizácia vznikla v roku 1903 odčlenením sa rusínskych veriacich z gréckokatolíckej farnosti Sv. Mikuláša v McKeesporte (predmestie Pittsburghu, Pennsylvánia) od Sojedinenija Greko-Katoličeskich Russkich Bratstv. Dôvodom odluky boli predošlé spory medzi editorom Amerikanského Ruského Viestnika P. Žatkovičom a pro-ukrajinsky orientovaným gréckokatolíckym sídelným biskupom S. S. Ortynskym. V roku 1909 sa sídlo organizácie prenieslo až do Stockettu (Montána). V 20. rokoch 20. storočia združovala táto organizácia približne 7 tisíc členov. V rokoch 1910-1916 vydávala táto organizácia pod vedením o. J. Hanulyau noviny Rusin/The Ruthenian a od roku 1917 až do roku 2000 noviny pod názvom Prosvita/The Englightenment. Prvých pätnást’ rokov bol editorom týchto novín o. V. Gorzó. V roku 2000 sa Sobranije Greko-Katholičeskich Cerkovnych Bratst opätovne zlúčilo so Sojedinenijem Greko-Kaftoličeskich Russkich Bratstv [Magocsi 2005].

21 Zo spomienok J. G. Gardoša vieme, že „protokol z tohto stretnutia nikdy nebol verejne publikovaný, a že sa nevie, kde sa tento protokol nachádza. Zapisovatelom bol o. Thoma Szabó z Brownville (Penssylvania)“ [ANRU-R 1919: 91]. 
V podvečerných hodinách podal o. A. Holosnyay návrh, aby boli požiadavky spísané do Memoranda pre prezidenta Spojených štátov Amerických Woodrowa Wilsona. ${ }^{22}$ Zostavením memoranda bol poverený o. V. Gorzó. V mesiacoch júl a august 1918 nebola zo strany predsedu ANRU-R o. N. Chopeya vyvinutá žiadna aktivita, a to aj napriek tomu, že memorandum mu už dávno predtým o. V. Gorzó odovzdal. Nečinnost’ predsedu ANRU-R o. N. Chopeya zjavne súvisela so silnou anti-kampaňou zo strany Slovákov, Ukrajincov, Lemkov i Mad’arov voči aktivitám Uhro-Rusínov. ${ }^{23}$

Ďalšie stretnutie sa uskutočnilo až v dňoch 30. septembra a 1. októbra $1918 \mathrm{v}$ meste Scrantom (Pennsylvánia). Kedže viacero zástupcov z radov duchovenstva sa tohto stretnutia nezúčastnilo, stretnutie nadobudlo podobu skôr pracovnej porady, ktorá doladila obsah memoranda spísaného o. V. Gorzóm. Za preklad memoranda do anglického jazyka bol pritom poverený M. J. Hanchin, aj ked’ ako uvádza J. G. Gardoš, „niekedy v tomto čase sa ešte ako súkromná osoba na zostavovaní memoranda začal podielat aj rusínsky advokát G. I. Žatkovič z Pittsburgu (Pennsylvánia) - syn jedného zo zakladatelov Sojedinenija a dlhoročného šéfredaktora Amerikanko Ruskoho Viesnika P. J. Žatkoviča" [ANRU-R 1919: 97]. Z tohto teda vyplýva, že nie G. I. Žatkovič vypracoval samotné memorandu, ako sa to v odbornej literatúre často uvádza, ale o. V. Gorzó, pričom G. I. Žatkovič sa len podielal na jeho anglickom preklade, a to spoločne s M. J. Hanchinom.

K samotnému stretnutiu zástupcov ANRU-R ${ }^{24} \mathrm{~s}$ vtedajším prezidentom USA W. Wilsonom došlo 21. októbra 1918 o 16:30 popoludní v Modrej izbe Bieleho domu. Audienciu u prezidenta zariadil a prezidentovi W. Wilsonovi zástupcov ANRU-R po mene predstavil kongresman za homesteadský volebný obvod G. E. Campbell. Následne prezidenta informoval aj o aktivitách Rusínov v USA a odovzdal slovo G. I. Žatkovičovi. Ten prečítal text memoranda, ktorého obsahom (v závere textu) boli aj nasledujúce požiadavky:

1. „Ak i najmenšie národnosti po vojne dostanú národnú nezávislost', potom aj my prosíme Vašu Excelenciu, aby sa pri dohovoroch uvažovalo i na Rusínov, aby sme sa aj my stali samostatným národom;

2. Pokial by nezávislost' pre Rusínov nebola možná, potom nech sa vytvorí spoločné usporiadanie, pozostávajúce $\mathrm{z}$ uhorských, haličských a bukovinských Rusínov;

3. Pokial by na mierovej konferencií súčasné štáty ostali v rámci pôvodných hraníc a aj Uhro-Rusíni ostanú v rámci teritória Uhorska, požadujeme od Vašej Excelencie na mierovej konferencii, aby svojim vplyvom zabezpečila, aby Uhro-Rusíni dostali možnost’ najširšej autonómie, aby bol v budúcnosti zabezpečený ich národný život“ [ANRU-R 1919: 99-102].

22 Oficiálny názov tohto memoranda bol Memorandum k Jeho Excellencii Woodrow Wilson, presidentu Spojenych štatov Americkych, ot Amerikanskej Narodnej Rady Uhro-Rusinov.

23 J. G. Gardoš vo svojich spomienkach túto situáciu opísal nasledovne: „Slováci nás nazývali ,madarónmi‘, Národná obrana ,zradcami‘, halickí Lemkovia a Ukrajinci ,separatistami“ a Mad’ari ,moskalami-panslávmi““ [ANRU-R 1919: 94].

24 Stretnutia s prezidentom USA W. Wilsonom sa za ANRU-R zúčastnili: J. G. Gardoš, A. Petach, G. H. Komloš, o. V. Gorzó, M. J. Hanchin a G. I. Žatkovič, ktorého úlohou bolo prečítat text memoranda prezidentovi W. Wilsonovi. Predseda ANRU-R o. N. Chopey sa audiencie u prezidenta W. Wilsona nezúčastnil, pričom svoju neúčast’ odôvodnil epidémiou španielskej chrípky a s tým spojeným neodkladným duchovným zaopatrením veriacich vo farnosti. Aby na memorande určenom pre prezidenta USA W. Wilsona nechýbal podpis predsedu ANRU-R, za dočasného predsedu bol delegátmi ANRU-R zvolený J. G. Gardoš [ANRU-R 1919]. 
Ked' G. I. Žatkovič asi po 15 minútach svoju reč ukončil, odovzdal memorandum prezidentovi W. Wilsonovi, načo ten reagoval slovami: „Gratulujem Vám k tomu, že Rusíni sú prvý národ, ktorý prakticky v americkom duchu pochopil a predložil svoje želania“ [ANRU-R 1919: 103]. Zároveň sa vyjadril i k predloženým požiadavkám memoranda: Úplnú nezávislost' Rusínov prezident W. Wilson označil za nepraktickú. Podla neho, „vytvorením mnohých nezávislých štátov by v Európe mohla nastat’ situácia, žeby nebolo dost’ velkých štátov, a teda by bol problém aj so zachovaním mieru medzi nimi“ [ANRU-R 1919: 107]. Delegácii zároveň odporučil, aby hladali spojenie s príbuznými národmi a vstúpili s nimi do federácie ako autonómny štát. Prítomných následne ubezpečil, že nezostanú ani v rámci niekdajšieho Uhorska, pričom sám im odporučil hladat’ spojenectvo s príbuznými - teda slovanskými národmi. Kedže v tej dobe sa vo Washinghtone D. C. kreovala Únia Stredo-Európskych Národov, ktorej cielom bolo pred celým svetom deklarovat nároky utláčaných národov na slobodu, prezident W. Wilson prítomným odporučil aj to, aby sa stali členom tejto únie [ANRU-R 1919].

Po približne 45 minútach sa stretnutie s prezidentom W. Wilsonom v Bielom dome ukončilo. Odtialto zástupcovia ANRU-R zamierili rovno do sídla Únie Stredo-Európskych národov, kde sa stretli s jej predsedom T. G. Masarykom, aby ho oboznámili o priebehu i výsledku stretnutia s prezidentom W. Wilsonom, ale najmä, aby spoločne prediskutovali možnosti d’alšej spolupráce. ${ }^{25} \mathrm{~T}$. G. Masaryk (v tom čase si už plne vedomý toho, že sa stane prezidentom slobodnej Československej republiky) prítomných zástupcov ANRU-R ubezpečil, že on sám nemá nič proti tomu, aby sa Uhro-Rusíni stali súčastou Únie Stredo-Európskych národov, no je potrebné, aby za tento návrh zahlasovali aj reprezentanti d’alších jedenástich národov, ktoré dovtedy toto zoskupenie tvorili. Oni mali rozhodnút, či uhorskí Rusíni sú samostatný národ a či budú prijatí do Únie Stredo-Európskych národov.

V utorok podvečer 22. októbra 1918 sa reprezentanti všetkých jedenástich národov spoločne s reprezentantmi ANRU-R presunuli z Washingtonu D. C. do Philadelphie (Pennsylvánia), kde sa od stredy 23. do soboty 26. októbra 2018 malo konat spoločné stretnutie zástupcov všetkých dvanástich národov k pripravovanému vyhláseniu Deklarácie Spoločných cielov suverénnych Stredoeurópskych národov. Na stretnutí reprezentoval každý národ len jeden reprezentant, pričom za reprezentanta ANRU-R bol delegovaný G. I. Žatkovič. Ten hned'v prvý deň stretnutia pred ostatnými reprezentantmi prehlásil, že „aktivity Rusínov sú nezávislé a oddelené od ukrajinských; že Ukrajinci majú svoju cestu rozvoja a svoje organizácie; a že Rusíni majú svoje dejiny a Ukrajinci svoje“, aj ked pripustil, „že medzi oboma národmi existuje jazyková blízkost“ [Švorc 1996: 29; Pop 2005: 276]. Ešte v ten istý deň boli Uhro-Rusíni prijatí za v poradí dvanásteho člena Únie Stredo-Európskych národov. Týmto aktom boli Uhro-Rusíni de iure uznaní za slobodný a plnohodnotný národ d’alšími jedenástimi národmi, a to Čechoslovákmi, Poliakmi, Juhoslovanmi, Ukrajincami, ${ }^{26}$ Litovčanmi, Rumunmi, nevykúpenými Grékmi, talianskymi iredentistami, Albáncami, Sionistami a Arménmi [Žatkovič 1921].

25 Na spoločnom stretnutí reprezentanti ANRU-R T. G. Masarykovi ešte odovzdali aj kópiu memoranda, ktoré predtým predložili prezidentovi W. Wilsonovi, pričom ten na titulnej strane memoranda napísal: „S Žatkovičem a jeho přátely ve Philadelpii raději, obšírňe 26. oct. 1918 o možnosti jejich připojení k našemu státu. Dají návrh“ [ Švorc 1996: 15, 28-29].

26 Ukrajincov na tomto stretnutí reprezentoval N. G. Ceglinsky. Na tomto príklade je možné jasne vidiet’, že Rusíni sú iný národ ako Ukrajinci. Podla nášho názoru, ak by platilo to, čo tvrdia mnohí pro-ukrajinskí 
K oficiálnemu podpísaniu a vyhláseniu Deklarácie Spoločných cielov suverénnych Stredoeurópskych národov ${ }^{27}$ došlo 26. októbra 1918 v Independence Hall v meste Philadelphia (Pennsylvánia), a to v tej istej miestnosti, v ktorej bola 4. júla 1776 podpísaná Deklarácia nezávislosti Spojených štátov. K podpísaniu Deklarácie Spoločných cielov suverénnych Stredoeurópskych národov došlo dokonca i na tom istom stole, pričom reprezentanti jednotlivých národov sa podpisovali i tým istým perom, ktorým v roku $1776 \mathrm{~J}$. Hancock podpísal Deklaráciu nezávislosti Spojených štátov. ${ }^{28} \mathrm{G}$. I. Žatkovič deklaráciu podpisoval ako piaty v poradí. Okrem neho boli pri tomto významnom historickom akte za ANRU-R prítomní ešte aj redaktor Amerikansko-Russkoho Viesnika M. J. Hanchin, (ktorý niesol zástavu Sojedinenija, kedže národná zástava Rusínov ešte nebola) a tiež J. G. Gardoš, G. H. Komloš a M. Juhasz ako členovia ANRU-R. Po podpísaní Deklarácie Spoločných cielov suverénnych Stredoeurópskych národov a po jej vyhlásení pred Independence Hall reprezentanti všetkých národov predniesli svoju slávnostnú reč. Tú Žatkovičovu viacerí prítomní označili za velmi krátku, no o to výstižnejšiu, ked’ prehlásil, že „vd’aka prozretel’nosti všemohúceho Boha a vdaka prostriedkom Spojených štátov amerických, Uhro-Rusíni sa stáli slobodnými“ [ANRU-R 1919: 106].

Počas stretnutia vo Philadelphii (Pennsylvánia), s najväčšou pravdepodobnostou ešte 25. októbra 1918, došlo aj k rozhovorom medzi T. G. Masarykom a G. I. Žatkovičom o možnosti federácie medzi Rusínmi a Čechoslovákmi [Žatkovič 1921]. Podla spomienok G. I. Žatkoviča, na jeho otázku „či si prezident Masaryk ako reprezentant Čechoslovákov vie predstavit’ spoločnú federáciu Rusínov s Čechoslovákmi“ T. G. Masaryk odpovedal, že „ak sa Rusíni rozhodnú pričlenit’ k Československej republike, budú spokojní v plne autonómnom štáte; pričom hranice budú tvorené tak, aby Rusíni boli spokojní“ [Žatkovič 1921: 5]. Zároveň však Žatkovičovi pripomenul aj problémy, s ktorými sa budú musiet’ Rusíni v novej situácii vysporiadat. ${ }^{29}$

Tieto rozhovory sú dôležité najmenej v dvoch rozmeroch:

1. Vymedzili budúcu spoluprácu medzi Rusínmi a Čechoslovákmi na federatívnom princípe usporiadania nového štátu, aj ked' reálne $\mathrm{k}$ tomu nikdy nedošlo.

2. Pripojenie územia obývaného Uhro-Rusínmi k Československej republike malo i geopolitický rozmer. ${ }^{30}$ Hranice novej Československej republiky sa tak posunuli až k Rumunsku, ktoré bolo považované za potenciálneho spojenca. V tomto duchu sa niesol i telegram, ktorý T. G. Masaryk zaslal E. Benešovi [Pop 2005; Pop 2011].

akademici, že Rusíni sú len starším pomenovaním Ukrajincov, potom by N. G. Ceglinsky ako reprezentant ukrajinského národa určite nesúhlasil s pričlenením Uhro-Rusínov do Únie Stredo-Európskych národov. Ako je vidiet' nestalo sa tak a na Deklarácii Spoločných cielov suverénnych Stredoeurópskych národov sú podpisy tak reprezentanta ukrajinského národa N. G. Ceglinského, ako aj reprezentanta rusínskeho národa G. I. Žatkoviča.

27 Táto deklarácia je známa tiež aj ako Philadelphská dohoda. Text deklarácie je dostupný na: <https://www.pitt .edu/ votruba/qsonhist/assets/1918-Philadelphia_Declaration_of_the_Mid-European_Nations.pdf>.

28 Americký milionár a humanista J. Wanamaker dal vyrobit’ dvanást’ kópií Liberty Bell a tiež dvanást’ kresiel podla vzoru kresla, na ktorom sedel J. Hancock, ked’ podpisoval Deklaráciu nezávislosti Spojených štátov amerických, teda jeden exemplár pre každý národ. Tým, že za československý národ deklaráciu podpisoval T. G. Masaryk a za Uhro-Rusínov deklaráciu podpisoval G. I. Žatkovič, Československá republika takto získala až dve kópie Liberty Bell a dve takéto kreslá.

29 K. Kadlec napríklad uvádza kultúrnu, vzdelanostnú i ekonomickú zaostalost’ Rusínov [Kadlec in. Chmelař Klíma - Nečas 1923].

30 Na geopolitický rozmer Uhorskej Rusi v rámci Československej republiky poukazujú viacerí autori [napríklad: Ištok in. Švorc-Danilák - Heppner (ed.) 2002: 13-21; Danilák in. Švorc-Danilák-Heppner (eds.) 2002: 59-82; Koziak In: Morávek - Landr (eds.) 1997: 57-60, ale aj mnohí d’alší]. 
Na základe týchto udalostí sa dňa 12. novembra 1918 v meste Scranton (Pennsylvánia) konalo zasadnutie ANRU-R, na ktorom sa prítomní delegáti mali možnosț v plebiscite vyjadrit’ k otázke budúceho štátoprávneho postavenia Uhorskej Rusi. ${ }^{31} \mathrm{Z}$ celkového počtu 1113 hlasov bolo 732 hlasov (čo predstavovalo takmer 66 \%) za integráciu Uhro-Rusínov v rámci Československej republiky; 310 hlasov bolo za integráciu Uhro-Rusínov s Ukrajinou; 27 hlasov bolo za samostatnost; 13 hlasov bolo za spojenie s haličskými Rusínmi a Rusínmi z Bukoviny; 10 hlasoval bolo za integráciu s Ruskom; 9 hlasov bolo za zotrvanie v rámci Mad’arska a 1 hlas bol za spojenie s Haličou [Danko 1968].

Výsledkom tohto plebiscitu bolo vyhlásenie rezolúcie, na základe ktorej „sa Uhro-Rusíni s najširšími samosprávnymi právami ako štát na federatívnom princípe pričleňujú k Československej demokratickej republike s tým, že do ich krajiny mali pripadnút všetky pôvodne uhro-ruské župy, a to: Spiš, Šariš, Zemplín, Abov, Gemer, Boršod, Uh, Ugoč, Bereg i Marmaroš“ [Žatkovič 1921: 5]. V nasledujúci deň bola kópia tejto rezolúcie odovzdaná T. G. Masarykovi, pričom o výsledku plebiscitu boli informovaní i prezident W. Wilson a tiež E. Beneš, ktorý bol už v tom čase na mierovej konferencii v Paríži [Danko 1968].

\section{Záver}

V závere tejto štúdie je možné konštatovat', že vzt’ahy medzi jednotlivými reprezentantmi uhorských Rusínov ešte aj na konci 1. svetovej vojny (či už doma v Uhorsku, alebo v emigrácii v USA) boli značne komplikované, neusporiadané a vel'mi často aj protichodné. Reprezentanti jednotlivých orientácií ich pritom často menili podla toho, ako sa menili vtedajšie politické udalosti. O tejto vnútornej fragmentácii v rámci rusínskeho hnutia a politickom chaose svedčí aj viacero novovzniknutých „národných rád“ - Prešovská, Užhorodská, Sval’avská, Chustská, Jasiňská, Marmarošská. Takýto politický zmätok rozhodne neprispieval štátoprávnym úvahám uhorských Rusínov v posledných mesiacoch končiacej 1. svetovej vojny.

Politicky najvýznamnejšia národná rada uhorských Rusínov pritom nevznikla doma, ale, paradoxne, v prostredí rusínskej emigrácie v USA. Hromadné vystahovalectvo uhorských Rusínov, ktoré sa najprv javilo ako pohroma tohto národa, sa neskôr ukázalo ako jeho záchrana v podobe národného obrodenia na úplne novej úrovni. Avšak aj v tomto prípade bolo prvoradým predpokladom úspechu zjednotenie protichodných postojov jednotlivých skupín. Potom, ako sa im to podarilo, mohli spoločnými silami postupovat' dalej. Najprv to boli rozhovory s vtedajším prezidentom USA W. Wilsonom v Bielom dome a následne i rozhovory s reprezentantmi d’alších 11 národov združených v Únii StredoEurópskych národov, ktorí uhorských Rusínov akceptovali a prijali medzi seba. Prvé kroky politickej budúcnosti uhorských Rusínov po 1. svetovej vojne sa teda kreovali v Spojených štátoch amerických.

Pokial' ide o postoje ANRU-R k pripojeniu Uhorskej Rusi k novovzniknutej Československej republike, tu je potrebné opätovne zdôraznit', že malo íst’ o usporiadanie na

31 Na plebiscite sa podielali všetky spolky Sojedinenija i Sobranija. Registrácia jednotlivých spolkov a farností sa uskutočnila prostredníctvom pošty, ale aj inými spôsobmi. Každý spolok alebo farnost̉ získala 1 hlas, ak mala 50 členov. Celkovo bolo do tohto plebiscitu zapojených približne 60-70 tisíc ludí [Danko 1968]. 
federatívnych princípoch, tak ako to rusínska emigrácia poznala v USA, a nie o autonómiu v rámci unitárneho štátu, a aj to $\mathrm{v}$ značne oklieštenej podobe. Počiatočné prísluby T. G. Masaryka zástupcom ANRU-R boli značne vzdialené od neskoršej reality. Pri spoločných rokovaniach prislúbil T. G. Masaryk uhorským Rusínom omnoho viacej, ako mohol neskôr reálne splnit’. Táto skutočnost’ bola začiatkom 20. rokov 20. storočia aj príčinou častých politických stretov medzi G. I. Žatkovičom a československou vládou v Prahe, čo viedlo aj k podaniu demisie zo strany G. I. Žatkoviča z postu guvernéra Podkarpatskej Rusi a jeho následný odchod spät’ do USA.

Napokon je nevyhnutné zdôraznit ešte jeden významný fakt, a to, že pri zrode Československej republiky boli nielen Česi a Slováci, ako sa to vel’mi často v českej i slovenskej verejnosti proklamuje, ale aj Rusíni. Aj ked’ ich podiel na kreovaní československej štátnosti bol podstatne menší ako v prípade Čechov a Slovákov, aj ich je potrebné vnímat ako štátotvorný národ Československej republiky. Aj vd’aka nim, nadobudlo Československo (minimálne) v stredoeurópskom priestore omnoho významnejší vplyv a postavenie. Výstižné sú slová historika P. Švorca, ktorý napísal, že „bez poznania dejín Podkarpatskej Rusi je aj poznanie histórie medzivojnového československého štátu neúplné“, pričom dodal, že „V období po druhej svetovej vojne sa v Československu účelovo ignorovali dejiny tohto východného cípu republiky, ktorý patril k najchudobnejším oblastiam“ [Švorc 1996: 4].

\section{Literatúra a pramene}

Declaration of Common Aims of the Independent Mid-European Nations in Convention Assembled at Independence Hall Philadelphia, Pennsylvania, United States of America, October twenty-sixth one thousand nine hundred and eighteen. [1918]. Pittsburgh, Pa.: University of Pittsburgh. Dostupné z: <https://www .pitt.edu/ votruba/qsonhist/assets/1918-Philadelphia_Declaration_of_the_Mid-European_Nations .pdf>.

Souvenir issued by ther Rusin Peoples Home Inc. On the occasion of dedication of thes corner stone, May fourth, nineteen hundred and nineteen [1919]. Homestead, Pa.: Rusin Peoples Home.

ANRU-R [1919]. Protokol/Zapisnica iz zasidanij narodnoho kongressa amerikanskich Rusinov, pod ochranoju i rukovodstvom Amerikanskoj Narodnoj rady Uhro-Rusinov, poderžannoho v Homestead, Pa., dňa 15-16-ho Sept. 1919-ho roka. Homestead, Pa.: Tipografija Amerikanskoho Russkoho Viestnika.

Danko, Joseph [1968]. Plebiscite of Carpatho-Ruthenians in the United States Recommending Union of Carpatho-Ruthenia with the Czecho-slovak Republic. The Annals of the Ukrainian Academy of Arts and Sciences in the United States XI/1964-1968 (1-2 / 31-32): 184-207.

Gbúrová, Marcela [2002]. Dotyky s politikou: Ján Kollár, L’udovít Štúr, Pavol Hečko, Ján Palárik, Jonáš Záborský, Svetozár Hurban Vajanský, Milan Hodža. Trenčín: Q-EX.

Gbúrová, Marcela [2017]. Štúrovo hladanie rovnováhy medzi „pospolitostou“ a „jednotlivostou“. In. Krno, S. Ludovít Štúr - Európan, národovec a reformátor. Bratislava: Kancelária Národnej rady Slovenskej republiky, s. 9-57.

Chmelař, Josef - Klíma, Stanislav - Nečas, Jaroslav [1923]. Podkarpatská Rus: Obraz poměru prírodních, hospodárských, politických, církevních, jazykových a osvětových. Praha: Orbis.

Konečný, Stanislav [2015]. Náčrt dejín Karpatských Rusínov. Prešov: Prešovská univerzita v Prešove, Ústav rusínskeho jazyka a kultúry.

Koziak, Tomáš [1997]. Niektoré medzinárodnopolitické determinanty pričlenenia Podkarpatskej Rusi k Sovietskemu zväzu. In. Morávek, Ján - Landr, Petr (ed.). Podkarpatská Rus a Československo. Sborník ze studentské vědecké konference konané 15.-16. ř́ijna 1997 v Hradci Králové. Hradec Králové, s. 57-60.

Loužek, Marek [2010]. Československá ústava 1920: Devadesát let poté. Praha: Centrum pro ekonomiku a politiku, č. 83 . 
Magocsi, Robert Paul [2005]. Our people: Carpatho-Rusyns and their descendants in North America. Wauconda, Il.: Bochazy-Carducii Publishers.

Magocsi, Robert Paul [1994]. Rusíni na Slovensku. Prešov: Rusínska obroda.

Magocsi, Robert Paul [1975]. The Rutheninan Decision to Unite with Czechoslovakia. Slavic Review 34 (2): 360-381.

Magocsi, Robert Paul [1993]. The Ukrainian Question Between Poland and Czechoslovakia: The Lemko Rusyn Republic (1918-1920 and Political Thought in Western Rus - Ukraine. Nationalities Papiers XXI (2): 360-381.

Magocsi, Robert Paul [2017]. Tradícia autonómie na Karpatskej Rusi. Historický časopis 65 (1): 79-97.

Mrva, Ivan - Segeš, Vladimír [2012]. Dejiny Uhorska a Slováci. Bratislava: Perfekt.

Pejša, Robert [2016]. Podkarpatská Rus v Československu 1919-1922. Právni a politicko-spoločenské aspekty připojení Podkarpatské Rusi k Československu. Praha: Karolinum.

Піпаш, Володимир [2009]. Гуиульська республіка - унікальна сторінка державотворення. Dostupné z: <https://zakarpattya.net.ua/News/34094-Hutsulska-respublika-\%E2\%80\%94-unikalna-storinka -derzhavotvorennia>.

Pop, Ivan [2005]. Dějiny Podkarpatské Rusi v datech. Praha: Libri.

Pop, Ivan [2011]. Malé dejiny Rusínov. Bratislava: Združenie inteligencie Rusínov Slovenska.

Rychlík, Jan - Rychlíková, Magdaléna [2016]. Podkarpatská Rus v dějinách Československa 1818-1946. Praha: Vyšehrad.

Šutajová, Jana [2015]. Problematika práv národnostných menšín v Československu. In. Eštok, Gabriel - Geffert, Richard - Bzdilová, Renáta. Ludské práva. Kam kráčaš demokracia. Košice: Univerzita Pavla Jozefa Šafárika v Košiciach, s. 273-285.

Šutajová, Jana [2015]. Vybrané kapitoly z dejín verejnej správy na Slovensku po roku 1918. Košice: Univerzita Pavla Jozefa Šafárika v Košiciach.

Švorc, Peter [1996]. Zakliata krajina (Podkarpatská Rus 1918-1946). Prešov: Universum.

Švorc, Peter - Danilák, Michal - Heppner, Harald (ed.) [2002]. Vel'ká politika a malé regióny 1818-1939. Prešov: Universum.

Zapletal, Florian [1921]. Rusíni a naši buditelé. Praha: Kolokol.

Žatkovič, Ignatius Grigorij [1921]. Expose Dr. G. I. Žatkoviča, byvšsho gubernatora Podkarpatskoj Rusi, o Podkarpatskoj Rusi. Homestead, Pa.: Rusin Information Bureau.

Alexander Onufrák pôsobí ako odborný asistent na Katedre politológie Filozofickej fakulty Univerzity Pavla Jozefa Šafárika v Košiciach. Hlavným predmetom jeho záujmu sú problematika medzinárodnej migrácie a integrácie migrantov, politické ideológie, problematika volieb a otázky súvisiace s rusínskou národnostnou menšinou. 